\title{
Palladium(II) pincer complexes of $\alpha$-amino acids: towards the synthesis of catalytically active artificial peptides
}

\author{
Gabriela Guillena, Gema Rodríguez and Gerard van Koten* \\ Debye Institute, Department of Metal-Mediated Synthesis, Utrecht University, Padualaan 8, 3584 CH Utrecht, The Netherlands
}

Received 28 March 2002; accepted 2 April 2002

\begin{abstract}
NCN palladium(II) complexes have been covalently attached to the N-and C-termini of L-valine and to the N-terminus of the dipeptide L-Phe-L-Val-OMe. Remarkably, the hydrolysis of the NCN-Pd(II) L-Val-OMe compound afforded the corresponding palladated, free amino acid without affecting the metal site. This deprotected amino acid could be coupled to any protein, enzyme or peptidic chain by simple peptide chemistry. These bioorganometallic systems were active as catalysts in the aldol reaction between methyl isocyanate and benzaldehyde. (C) 2002 Elsevier Science Ltd. All rights reserved.
\end{abstract}

The design of peptides that mimic the structural and/or functional features of naturally occurring proteins has lately become an area of interest. ${ }^{1}$ The ability of small polypeptide chains to fold in secondary structures provides a unique platform to build man-made enzyme-like systems for both biological or non biological reactions. Incorporation of catalytically active transition-metal complexes to these biomolecules affords the development of chiral compounds with unique selectivity and potential applications in enantioselective synthesis. ${ }^{2}$ Commonly, this introduction of the metal site at different positions of the peptidic chain occurs in the last step of the synthesis. ${ }^{3}$ Our approach to the synthesis of metallated peptides consists of the attachment of transition-metal complexes of type [MX(NCN)] (NCN is the monoanionic, para-functionalized 'pincer' ligand $\left.\left[\mathrm{C}_{6} \mathrm{H}_{2}\left(\mathrm{CH}_{2} \mathrm{NMe}_{2}\right)_{2}-2,6\right]^{-}\right)^{4}$ to amino acids and peptides.

Herein, we report on the successful binding of NCN 'pincer' ligands to the $\mathrm{N}$ - and $\mathrm{C}$-termini of $\alpha$-amino acids and dipeptides as well as their palladation with the concomitant creation of biofunctionalized systems with catalytically active sites. The preliminary results obtained in the use of these organopalladium(II) complexes as homogeneous catalysts in the aldol condensation reaction of benzaldehyde and methyl isocyanate are also described. ${ }^{5}$

Condensation of the aldehyde 1 with the hydrochloride form of the methoxy-protected L-valine (L-Val-OMe) in the presence of $\mathrm{MgSO}_{4}$ led to the formation of a Schiff

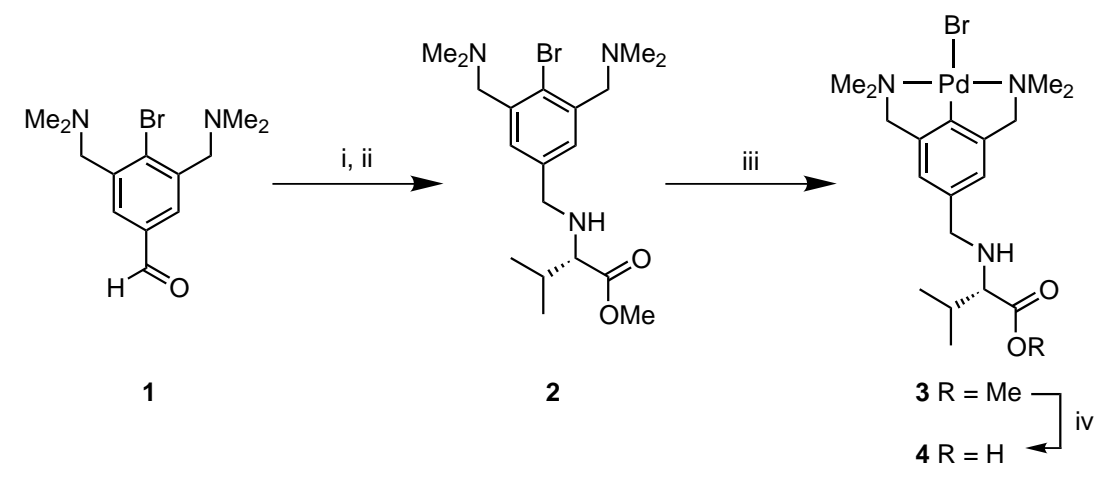

Scheme 1. Reagents and conditions: (i) (a) L-Val-OMe $\cdot \mathrm{HCl}, \mathrm{NEt}_{3}, \mathrm{MgSO}_{4}, \mathrm{rt}, 12 \mathrm{~h}$; (b) $\mathrm{HOAc} \mathrm{NaBH}_{3} \mathrm{CN}, \mathrm{MeOH}^{\circ}{ }^{\circ} \mathrm{C}, \mathrm{rt}, 2 \mathrm{~h}$, $87 \%$; (ii) $\left[\mathrm{Pd}_{2}(\mathrm{dba})_{3} \cdot \mathrm{CHCl}_{3}\right]$, toluene, $\Delta, 3 \mathrm{~h}, 79 \%$; (iii) $\mathrm{LiOH}, \mathrm{THF} / \mathrm{H}_{2} \mathrm{O}, \mathrm{rt}, 12 \mathrm{~h}, 71 \%$.

\footnotetext{
* Corresponding author. Tel.: +31-30-2533120; fax: +31-30-2523615; e-mail: g.vankoten@chem.uu.nl 
base which could be easily reduced with $\mathrm{NaBH}_{3} \mathrm{CN}$ affording the $\mathrm{N}$-terminus pincer functionalized valine $\mathbf{2}$ (Scheme 1). ${ }^{6}$

As the $\left[\mathrm{PdX}_{n} \mathrm{~L}_{m}(\mathrm{NCN})\right]$ complexes are catalytically active metallation of $\mathbf{2}$ with $\left[\mathrm{Pd}_{2}(\mathrm{dba})_{3} \cdot \mathrm{CHCl}_{3}\right]$ was attempted which indeed resulted in clean formation of the Pd(II)-valine complex 3. The signals of the $\mathrm{NMe}_{2}$ and $\mathrm{ArCH}_{2} \mathrm{~N}$ moieties were characteristically shifted to lower field 2.94 and $3.96 \mathrm{ppm}(\Delta \delta=0.63$ and 0.43 $\mathrm{ppm}$ ), respectively, while the signal corresponding to the aromatic protons appeared at higher field, $6.75 \mathrm{ppm}$ $(\Delta \delta=0.54 \mathrm{ppm})$.

More interesting would be the deprotection of the $\mathrm{N}$-terminus organopalladated $\alpha$-amino acids 3, enlarging the field of application of this system. Deprotected amino acids could be coupled to any protein, enzyme or peptidic chain by simple peptide chemistry. Interestingly, the $\mathrm{N}$-terminus palladated compound $\mathbf{3}$ could be easily hydrolyzed. Treatment of a THF $/ \mathrm{H}_{2} \mathrm{O}$ solution of 3 with $\mathrm{LiOH}$ afforded deprotected $\mathbf{4}$ without affecting the $\mathrm{Pd}-\mathrm{C} \sigma$-bond. Compound $\mathbf{4}$ was isolated as a lithium salt and then converted into the acid form by ion exchange column chromatography $(70 \%$ yield, Scheme 1).

The route developed for $\mathbf{4}$ should also be applicable to the attachment of these organometallic units to the $\mathrm{N}$-termini of peptides or to lateral chains of amino acids forming part of a peptidic chain. As a proof of principle the NCN moiety was linked at the N-terminus of the dipeptide L-Phe-L-Val-OMe affording compound 5 (Scheme 2).

The palladated dipeptide 6 was obtained by metallation of the $\mathrm{C}_{\mathrm{ary}}-\mathrm{Br}$ bond with $\left[\mathrm{Pd}_{2}(\mathrm{dba})_{3} \cdot \mathrm{CHCl}_{3}\right]$. The fact that the ${ }^{1} \mathrm{H}$ NMR spectrum of 6 showed only one resonance pattern indicated that the coupling of the pincer ligand 1 occurs with retention of configuration of $\mathrm{C}_{\alpha}$ of the dipeptide L-Phe-L-Val-OMe.

The incorporation of the organopalladated counterpart to the C-terminus of an $\alpha$-amino acid or/and higher molecular entities like polypeptides, would extend the application of these systems in catalysis. Therefore, we decided to attach the 'pincer' ligand to the C-terminus of Boc-protected L-valine ( $N$-Boc-L-Val). In order to avoid racemization of the enantiomerically pure starting $\alpha$-amino acid, standard peptide chemistry was applied in this synthesis.

Aldehyde 1 was reduced to the required alcohol for the $\mathrm{C}$-functionalisation of valine. Thus, treatment of a methanol solution of 1 with $\mathrm{NaBH}_{4}$ at room temperature afforded the benzylic alcohol 7 in a good yield (Scheme 3). Further condensation of 7 with Boc-protected L-valine in the presence of DCC and 4-DMAP led to $\mathrm{C}$-pincer functionalized valine $\mathbf{8}$. Oxidative addition of $\left[\mathrm{Pd}_{2}(\mathrm{dba})_{3} \cdot \mathrm{CHCl}_{3}\right]$ to the $\mathrm{C}_{\text {aryl }}-\mathrm{Br}$ bond of $\mathbf{8}$ gave rise to the organometallic $\alpha$-amino acid ester 9 in a $76 \%$ yield.
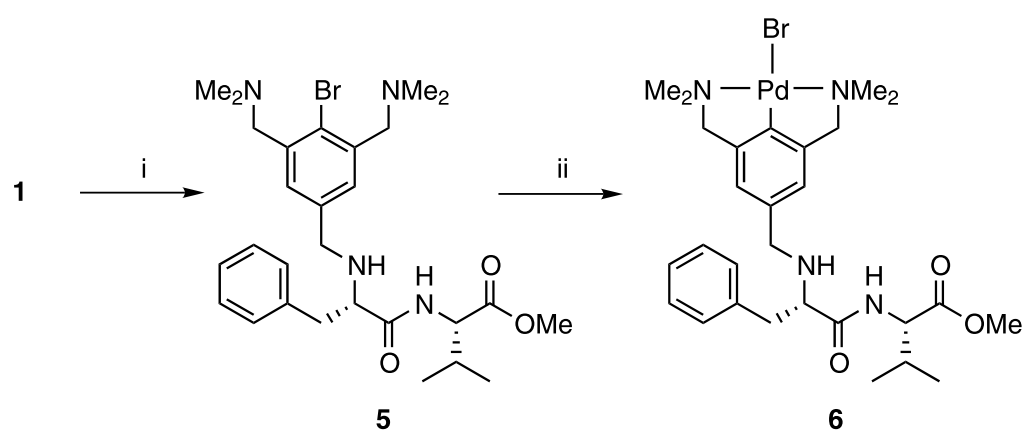

Scheme 2. Reagents and conditions: (i) (a) L-Phe-L-Val-OMe $\cdot \mathrm{HCl}, \mathrm{NEt}_{3}, \mathrm{MgSO}_{4}, \mathrm{rt}, 12 \mathrm{~h}$; (b) $\mathrm{HOAc} \mathrm{NaBH}_{3} \mathrm{CN}, \mathrm{MeOH}, 10^{\circ} \mathrm{C}$, rt, $2 \mathrm{~h}, 58 \%$; (ii) $\left[\mathrm{Pd}_{2}(\mathrm{dba})_{3} \cdot \mathrm{CHCl}_{3}\right]$, toluene, $\Delta, 3 \mathrm{~h}, 40 \%$.

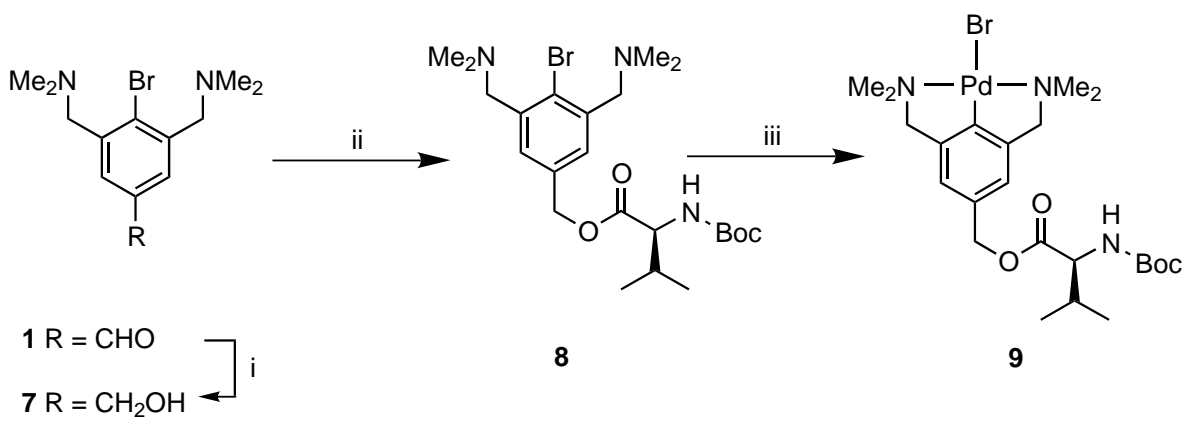

Scheme 3. Reagents and conditions: (i) $\mathrm{NaBH}_{4}, \mathrm{MeOH}, \mathrm{rt}, 2 \mathrm{~h}, 95 \%$; (ii) DCC, 4-DMAP, Boc-L-Val-OH, rt, 12 h, 71\%; (iii) $\left[\mathrm{Pd}_{2}(\mathrm{dba})_{3} \cdot \mathrm{CHCl}_{3}\right]$, toluene, $\Delta, 3 \mathrm{~h}, 76 \%$. 
The $\mathrm{Pd}^{\mathrm{II}}$ complexes 3, 4, 6 and 9 were used as catalyst precursors in the aldol condensation reaction of benzaldehyde and methyl isocyanoacetate to form an oxazoline.

Consequently, 3, 4, 6 and 9 were converted into their corresponding cationic analogues by abstracting the halide anion using $\mathrm{AgBF}_{4}$ in wet acetone. ${ }^{7}$ After appropriate work-up involving a thorough filtration, through a path of Celite, of the solutions containing the cationic complexes to remove the insoluble silver salts, ${ }^{\dagger}$ active catalytic species were isolated and used without further purification in the aldol condensation reaction.

These preliminary experiments were carried out with $i$ - $\mathrm{Pr}_{2}$ EtN (Hunig's base, $10 \mathrm{~mol} \%$ ) as base, using $1 \mathrm{~mol} \%$ of the catalyst, methyl isocyanoacetate $(100 \mathrm{~mol} \%)$ and benzaldehyde $(100 \mathrm{~mol} \%)$ in dichloromethane at room temperature.

The catalytic results are presented in Table 1, and are compared with the activity of the corresponding $[\mathrm{PdCl}(\mathrm{NCN})]$ and $\mathrm{N}$-benzyl protected valine (10) as well as the uncatalyzed reaction.

The catalytic activities of the biofunctionalized Pd(II) complexes 3, 6 and 9 are similar to the non-functionalized $[\mathrm{PdCl}(\mathrm{NCN})]$ compound. The best results were obtained when the palladated free $\alpha$-amino acid $\mathbf{4}$ was used as a catalyst. Most probably the carboxylic moiety present in 4 interacts with some of the intermediates of the reaction since the palladium-free analog $\mathbf{1 0}$ displays much lower catalytic activity.

Unfortunately, the stereogenic centers present in compounds 3, 4, 6 and 9 do not have any influence on the stereoselectivity of the reaction. These centers are most probably too far away from the reactive site. Therefore, the introduction of the $\mathrm{Pd}(\mathrm{II})$ complex in higher peptidic chains or biomolecular entities is necessary for the induction of chirality in the aldol condensation reaction.
In summary, we have developed a new methodology for the successful binding of $\alpha$-amino acids and peptides at their $\mathrm{N}$ - and C-terminus to NCN-palladium(II) complexes. These biometallic systems were active in the catalytic aldol reaction between methyl isocyanate and benzaldehyde. The preparation of the free, organopalladated $\alpha$-amino acids allows the incorporation of these catalytic units in higher molecular structures such as peptides or proteins. Their chiral environment should definitely influence the stereochemistry of the catalytic reaction.

\section{Acknowledgements}

G. Guillena and G. Rodríguez are Marie Curie fellows and thank the European Commission for a TMR Grant (Contract No. HPMF-CT-2000-00472 and HPMF-CT1999-00236, respectively). This work was also supported by the Council for Chemical Sciences from the Dutch Organisation for Scientific Research (CWNWO).

\section{References}

1. (a) Vasbinder, M. M.; Jarvo, E. R.; Miller, S. J. Angew. Chem. 2001, 113, 2906-2909; Angew. Chem., Int. Ed. 2001, 40, 2824-2827; (b) Motherwell, W. B.; Bingham, M. J.; Six, Y. Tetrahedron 2001, 57, 4663-4686; (c) Ghadiri, M. R.; Soares, C.; Choi, C. J. Am. Chem. Soc. 1992, 114, 4000-4002.

2. (a) Gilbertson, S. R.; Lan, P. Org. Lett. 2001, 4, $2237-$ 2240; (b) Gilbertson, S. R.; Collibee, S. E.; Agarkov, A. J. Am. Chem. Soc. 2000, 122, 6522-6523.

3. (a) Luchaco-Cullis, C. A.; Mizutani, H.; Murphy, K. E.; Hoveyda, A. H. Angew. Chem. 2001, 113, 1504-1508; Angew. Chem., Int. Ed. 2001, 40, 1456-1460; (b) Josephsohn, N. S.; Kuntz, K. W.; Snapper, M. L.; Hoveyda, A. H. J. Am. Chem. Soc. 2001, 123, 11594-11599.

Table 1. Aldol condensation reaction of methyl isocyanate and benzaldehyde ${ }^{\mathrm{a}, \mathrm{b}}$

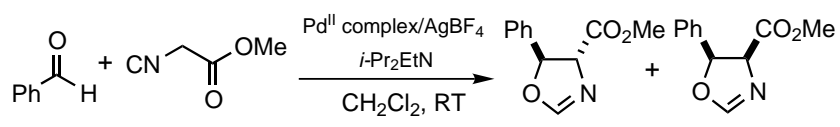

trans cis

\begin{tabular}{llcrrr}
\hline Entry & Pd(II) complex & Time $(\mathrm{h})$ & TOF & Conversion $^{\mathrm{c}}(\%)$ & trans $^{\prime} /$ cis $^{\mathrm{c}}$ \\
\hline 1 & None & 5 & 0 & 0 & - \\
2 & {$[$ PdCl(NCN)] } & 7 & 43 & 83 & $62: 38$ \\
3 & BnValOH (10) & 24 & 1 & 18 & $80: 20$ \\
4 & $\mathbf{3}$ & 7 & 52 & 96 & $62: 38$ \\
5 & $\mathbf{4}$ & 3 & 62 & 79 & $64: 36$ \\
6 & $\mathbf{6}$ & 7 & 40 & 97 & $68: 32$ \\
7 & $\mathbf{9}$ & 7 & 30 & 94 & $62: 38$ \\
\hline
\end{tabular}

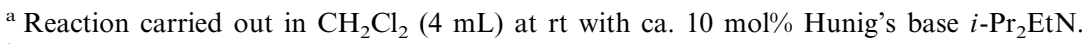

${ }^{\mathrm{b}}$ In all catalytic rounds the amount of palladium was kept constant (i.e. ca. $1 \mathrm{~mol} \%$ ).

${ }^{\mathrm{c}}$ Conversion and trans/cis ratio calculated using specific signal integration in ${ }^{1} \mathrm{H}$ NMR spectra.

\footnotetext{
${ }^{\dagger}$ This is important to note as the precipitated silver salt can also act as a Lewis acid catalyst.
} 
4. (a) Albrecht, M.; van Koten, G. Angew. Chem. 2001, 113, 3866-3898; Angew. Chem., Int. Ed. 2001, 40, 3750-3781; (b) Rietveld, M. H. P.; Grove, D. M.; van Koten, G. New J. Chem. 1997, 21, 751-771; (c) van Koten, G. Pure Appl. Chem. 1989, 61, 1681-1694.

5. (a) Longmire, J. M.; Zhang, X.; Shang, M. Organometallics 1998, 17, 4374 4379; (b) Stark, M. A.; Richards, C. J. Tetrahedron Lett. 1997, 38, 5881-5884; (c) Nesper, R.; Pregosin, P.; Püntener, K.; Wörle, M.; Albinati, A. J. Organomet. Chem. 1996, 507, 85-101; (d) Gorla, F.; Togni, A.; Venanzi, L. M.; Albinati, A.; Lianza, F. Organometal- lics 1994, 13, 1607-1616; (e) Nesper, R.; Pregosin, P. S.; Püntener, K.; Wörle, M. Helv. Chim. Acta 1993, 76, 2239-2249; (f) Hayashi, T.; Sawamura, M.; Ito, Y. Tetrahedron 1992, 48, 1999-2012.

6. (a) Guillena, G.; Rodríguez, G.; Albrecht, M.; van Koten, G., manuscript in preparation; (b) Albrecht, M.; Rodríguez, G.; Schoenmaker, J.; van Koten, G. Org. Lett. 2000, 2, 3461-3464.

7. Grove, D. M.; van Koten, G.; Louwen, J. N.; Noltes, J. G.; Spek, A. L.; Ubbels, H. J. C. J. Am. Chem. Soc. 1982, 104, 6609-6616. 